\begin{tabular}{|l|l|l|l|l|l|l|}
\hline Proftle & H PH life for pheochromocytoma & P1-P8
\end{tabular}

\title{
My life for pheochromocytoma
}

\author{
Hartmut P H Neumann \\ Unit for Preventive Medicine, Department of Nephrology and General Medicine, Albert-Ludwigs-University of \\ Freiburg, Hugstetter Street 55, D-79106 Freiburg, Germany
}

Correspondence should be addressed to H P H Neumann Email

hartmut.neumann@ uniklinik-freiburg.de

\section{Introduction}

A fascination with hereditary tumor diseases, especially Von Hippel-Lindau (VHL) disease and pheochromocytoma, has dominated my academic life for three decades (Table 1, Fig. 1). My background was the warm and rich atmosphere created by my parents Colonel Joachim Neumann and Mechtild Zuckschwerdt, PhD, MA, descendent of an industrial family from Magdeburg. Together with three sisters and a brother, I spent my youth in Brunswick, Hamburg, and Bonn with a classical education including Latin and Greek. I served 2 years in the artillery of the German army. From 1969 to 1974, I studied medicine at the Universities of Bonn and Heidelberg.

After examination, I felt unprepared for a university career. I started in internal medicine in a country hospital, but decided after some months to move into pathology in the large city hospital of Ludwigshafen/Rhein, the city of the BASF company. The 5-year training programme of 500 autopsies, 20000 biopsies and operation specimens, dominated by the cultured personality of the head Kurt Wegener, gave me a solid background. However, returning to the wards at the University Clinics of Freiburg at the age of 34 years was not promising: in this country, I was considered too old.

\section{The early years at the University of Freiburg}

The year was 1983: as a member of a nephrology department, I realized that the causes of diseases, especially glomerulonephritis, were unlikely to be clarified soon (still not achieved even today!). The key event happened within 2 months, when I had charge of a patient with pheochromocytoma (Table 1). His sister informed me that she had been operated on for a brain tumor, a hemangioblastoma. Overnight, I realized that the diagnosis must have been VHL. The gene was neither mapped nor identified at that time, and I had secondary hypertension with a defined cause (inheritance) to consider, the basis for clinical and basic research for years. The many aspects of clinical relevance were fascinating: diagnosis and treatment of pheochromocytoma and hemangioblastoma of the CNS, and the other components of VHL, retinal (hem)angio(blasto)ma, clear-cell renal cancer, and pancreatic neuroendocrine tumors. However, I was in a section of nephrology and my proposed clinical and research platform encompassed multiple disciplines, resulting in a lack of support from my own department. In other words, I wanted to study a unicorn: too rare, too many disciplines; hence hopeless. I therefore respectfully requested joint appointments with the chiefs of the eye, neurosurgery, and visceral surgery departments. I was then able to review the patients belonging to all three departments and made three lists. I noticed some identical family names across the three lists, while others all lived in the same small locations. I contacted these patients and with their permission, I drove after work through the Black Forest to meet the families, to collect information and blood samples. The number of VHL patients grew.

After revising the diagnostic criteria for VHL (Neumann 1987a) and its prognosis (Neumann 1987b), I started publishing in international scientific journals with a report on sporadic and VHL-associated CNS hemangioblastomas (Neumann et al. 1989). After disappointing ventures with distinguished international research groups to help identify the VHL gene, I joined the Bostonian group and later the Cambridge, UK group, achieving only an acknowledgment in the Nature publication (Mulligan 1993), I decided to try on my own a major manuscript without molecular genetic data.

Published by Bioscientifica Ltd. 
Table 1 Von Hippel-Lindau disease: major manifestations and clinical classification

Retinal angiomas

Hemangioblastomas of the CNS

Clear-cell renal carcinomas

Pheochromocytomas

Pancreatic neuroendocrine tumors

Epididymal cystadenomas/cystadenomas of the broad ligament

In VHL type 1, renal carcinomas are predominantly present, but pheochromocytomas are very rarely present. In VHL type 2, pheochromocytomas are predominantly present, but renal carcinomas are very rarely present. Especially in VHL type 2A, kidney tumors are exceptions, but not in VHL type $2 \mathrm{~B}$, whereas in VHL type $2 \mathrm{C}$, as a rule, only pheochromocytomas are present.

The breakthrough was in 1991 with the Lancet publication on the epidemiology and classification of VHL (Neumann \& Wiestler 1991), which is still being used now to distinguish between VHL types 1 and 2 (Plate et al. 2007) (Table 2). The other major project from this period still remains as the only prospective study for the clinical diagnosis of pheochromocytoma, and was published in 1993 in the New England Journal of Medicine (Neumann et al. 1993). In 36 of the 79 investigated at-risk persons from 24 families with this tumor, we found 42 new pheochromocytomas. We were able to compare the sensitivity and specificity of ultrasonography, computerized tomography, magnetic resonance tomography, metaiodobenzylguanidine scintigraphy, and biochemical methods to detect pheochromocytoma. For this publication, I received the highest award of the German Society of Nephrology, the Franz-Volhard Prize in 1994.

\section{Academic career}

Although, I was initially deemed too old, I completed specialization in Internal Medicine (1988), Nephrology (1990), and Endocrinology (1994) at the University Medical Center of Freiburg and was appointed Privatdocent (1988) and subsequently Extraordinary Professor (1994). Around that time, I established a molecular genetic laboratory for both research and clinical genetic diagnostics. In 1996, I won the competition for the chief position of the Department of Nephrology at the University of Innsbruck. I had to decline that position due to terms that would have doomed me to failure. This ended in the tragedy of my laboratory staff departing, thinking that I would accept the position at Innsbruck, and I was never invited again for a chief position. However, all things in life happen for a good reason.

\section{Scientific fruits}

In 1996 and 1997, I reorganized my laboratory with successful grant applications and a staff of up to ten postdocs, technicians, and students based on projects for break as pheochromocytoma and associated syndromes, hemolytic uremic syndrome, and autosomal dominant polycystic kidney disease, funded by the German Cancer Foundation, the German Research Foundation, and the Else Kroener-Fresenius Foundation. The research group was formally incepted in 2006 as the Section for Preventive Medicine. In fact, the focus of our activities was the work 'at the edge' of the molecular classification of tumors and diseases by identification of germline mutations in the blood of patients in order to establish programs for best treatment and follow-up, and to archive optimal long-term outcomes. For this objective, it turned out that outstanding large registries are essential. We established these registries for all component tumors of VHL and sporadic counterparts, e.g. retinal angiomas, CNS hemangioblastomas, renal clear-cell cancer, and neuroendocrine tumors. One of our most unique initiatives comprises the 2000-registrant strong European-American Pheochromocytoma-Paraganglioma Registry based in Freiburg. This Registry contains all forms of hereditary and sporadic pheochromocytomas and paragangliomas including those of the skull base, neck, and thoracic and pelvic locations. In parallel, we have established similar registries in Freiburg for hemolytic uremic syndrome, autosomal dominant polycystic kidney disease, and Fabry disease.

\section{The Freiburg-Warsaw-Columbus Pheochromocytoma Study}

The pheochromocytoma registry started with a local collection gained by systematic offers not only to

Table 2 Pheochromocytomas and paragangliomas: molecular genetic classification

Multiple endocrine neoplasia type 2 associated with mutations in RET Von Hippel-Lindau disease associated with mutations in VHL

Paraganglioma syndrome type 1 associated with mutations in SDHD Paraganglioma syndrome type 2 associated with mutations in SDHAF1 Paraganglioma syndrome type 3 associated with mutations in SDHC Paraganglioma syndrome type 4 associated with mutations in $S D H B$ Paraganglial tumors associated with mutations of TMEM127 Paraganglial tumors associated with mutations in MAX Paraganglial tumors associated with mutations in SDHA

The nomenclature is not always the same. According to the WHO classification, the term pheochromocytoma is restricted to adrenal tumors. Most clinicians say pheochromocytoma when the tumor is vasoactive with attacks of hypertension, sweating and headaches and reserve paraganglioma to those of skull base and neck locations.

Published by Bioscientifica Ltd. 
endocrinologists, pediatricians, and visceral surgeons in Germany, but also to colleagues abroad. Wlodzimierz Januszewicz, Head of the Department of Hypertension at the Medical Academy of Warsaw, admired our abovementioned 1993 paper. At a meeting in Berlin in 1996 I was conferred honorary membership of the Polish Society of Hypertension by his son, Andrzej Januszewski. The registry was dramatically enlarged by Polish patients including blood samples from all cases. When mutations of the $S D H B$ and $S D H D$ genes were shown in patients with paraganglioma syndrome types 1 and 4 in 2000, Birke Bausch, then a medical student in my laboratory, completed molecular genetic testing analyses in 271 patients with apparently sporadic pheochromocytomas. The design, interpretation, and manuscript together with Charis Eng, then in Columbus, Ohio, were published in 2002 in the New England Journal of Medicine (Neumann et al. 2002). The editorial summarized the message as 'The death of an axiom' (Dluhy 2002). Indeed, the anticipated $10 \%$ heredity in pheochromocytomas exploded to $24 \%$; all four genes contributed considerably. This publication now has more than 900 citations in peer-reviewed journals.

\section{The grant of the European Union}

Soon after this publication, I was contacted by the Finnish geneticist Lauri Aaltonen and invited to apply in a group of six for a grant to be submitted to the European Union on Defects in the Tricarboxylic Acid (Krebs) Cycle Genes in Tumourigenesis, EU Project No. LSHC-CT-2005-518200. The application was fully granted and provided an optimal basis for the coming years. We extended our activities to head-and-neck paragangliomas and reported on the spectrum of germline mutations and clinical manifestations for $S D H B$ and $S D H D$ in 2004 and for $S D H C$ in 2005, both in the Journal of the American Medical Association (Neumann et al. 2004, Schiavi et al. 2005). Subsequently, we elaborated guidelines for the selection of candidate genes to be tested in patients with pheochromocytoma in Clinical Cancer Research (Erlic et al. 2009) and patients with head-and-neck paragangliomas in Cancer Research (Neumann et al. 2009).

\section{Felix Fränkel's report from 1886 on Minna Roll: first description of an heritable pheochromocytoma}

The keynote speaker at the 1st International Symposium on Pheochromocytoma in Bethesda, Maryland in 2005,
William M Manger, at that time President of the American Society of Hypertension, gave credit to the report of Fränkel, widely regarded as the first description of pheochromocytoma (Fränkel 1886). It was a patient treated in Freiburg and thus a new challenge for me. In fact, this report, which had been translated to English before (Fränkel 1984), has remarkable features: a 19-year-old patient, bilateral adrenal tumors, histological diagnoses of a 'sarcoma' in one adrenal gland and 'angiosarcoma' in the contralateral side, with no affected relatives. Unlike the current regulatory environment, the Fränkel report names his patient as Minna Roll and the village where she lived as Wittenweier, $50 \mathrm{~km}$ north of Freiburg. Anticipating potential heredity based on young age and multifocal tumors, we estimated, based on our registry with patients up to 19 years, more than one tumor and the ZIP codes of places of residence. In all estimates, Minna Roll should have a high likelihood of having a VHL germline mutation. Once I returned from the meeting, I started an in-depth survey for records or other documents in the medical clinic, the institute of pathology, and the university library. I found a handwritten macroscopic autopsy report, no drawings, and no slides. I asked Alexander Vortmeyer from the NIH to check the extensive histological description in the publication. He agreed with a final diagnosis according to the actual tumor classification as bilateral pheochromocytomas. I decided to contact by mail 20 individuals carrying the same family name (Roll) from the Wittenweier telephone directory. I received positive answers and invitations for visits. Thus, I learned that all inhabitants of the village and interested persons like me had access to a book with pedigrees of all families of the village. This and information provided by the families gave evidence that descendents of two of the six brothers of Minna Roll had been recently operated on for pheochromocytomas. We had access to blood collected from these patients, and to our tremendous surprise, we did not find a VHL mutation. The mutation detected was in the RET gene (p.Cys634Trp), a common pathogenic RET mutation. Thus, we had evidence that the classical report on pheochromocytoma was a patient with multiple endocrine neoplasia type 2 . We were happy and proud that again the New England Journal of Medicine published this work (Neumann et al. 2007).

\section{The fight for adrenal-sparing and endoscopic surgery in hereditary pheochromocytoma}

Present in the operating theater for my first patient with bilateral and hereditary pheochromocytoma in 1983 and asking why complete removal of both adrenals is indicated, the response was 'You will do the surgery for

Published by Bioscientifica Ltd. 
the recurrent tumor' and bilateral complete removal was done. This spurred me to create the concept of adrenalsparing surgery in hereditary pheochromocytoma. My vision was that recurrence, if at all, would happen many years later, that malignancy is unlikely, and that a considerable number of hereditary pheochromocytomas are diagnosed at an asymptomatic stage after family screening or (only available many years later) molecular genetic testing. With this concept, one major burden to the patients, e.g. lifelong steroid replacement for postoperative Addison's disease, could be avoided. Since 1985, all my patients have been operated on accordingly, in the first few years by Helmut Kirste in an open procedure (Neumann et al. 1999). The extended concept was Endoscopic Adrenal Sparing Surgery. Thanks to the surgeon Martin Walz in Essen, this concept is now the gold standard, and I am happy to say that all my 150 pheochromocytoma patients operated on by Martin Walz had endoscopic tumor removal, all with retroperitoneal access with minimal scars, all were discharged after 2-4 days, and all preserved sufficient adrenal cortical tissue with no recurrence after a mean of 7 years. This series also includes an additional 30 patients with extra-adrenal pheochromocytomas, some of whom had difficult-to-reach or tenuous locations within the thorax or pelvis, all successfully removed endoscopically (Fig. 1).

\section{A dream come true: author in Harrison's Textbook of Internal Medicine}

In 2007, I received an email from the editorial team of Harrison's Textbook of Internal Medicine. I was asked to write the chapter pheochromocytoma. My response was that such a chapter would lie best in the hands of Lewis Landsberg. But it was Lew who had suggested me as he wanted to 'retire' from this chapter. What a challenge! With the excellent mentorship of Larry Jameson, I presented the generally accepted genetic classification
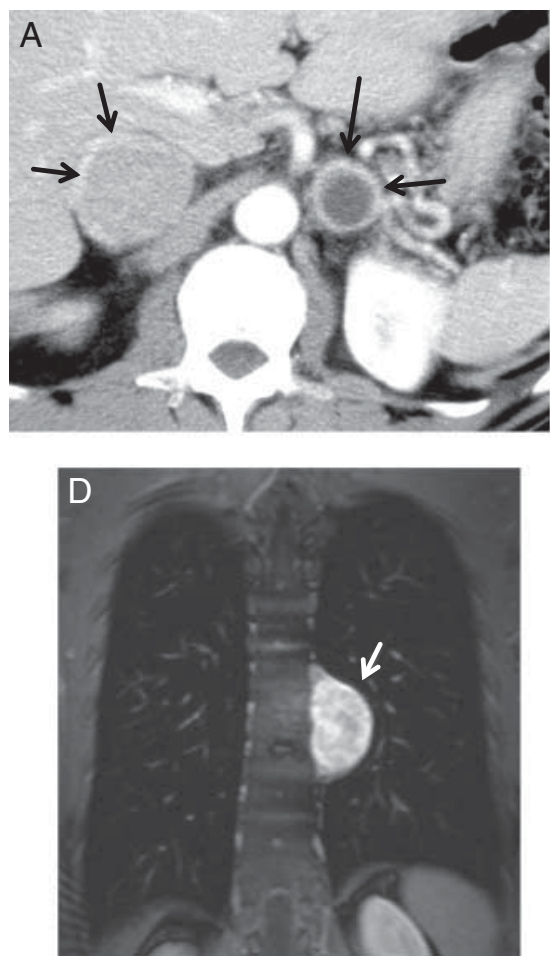
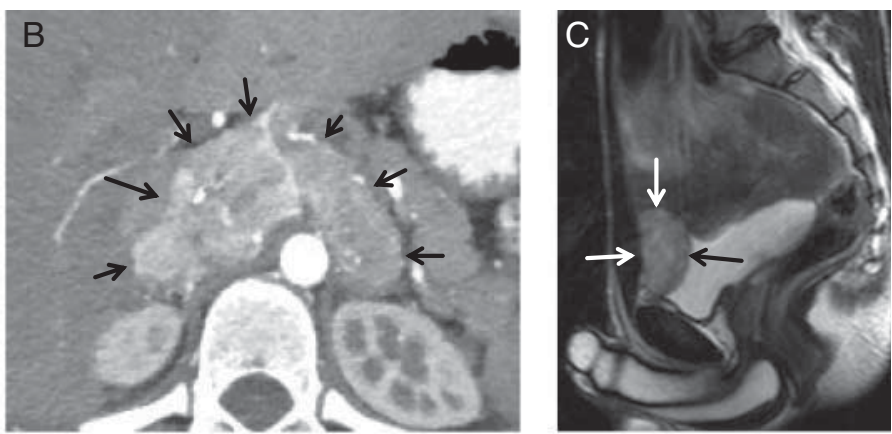

E

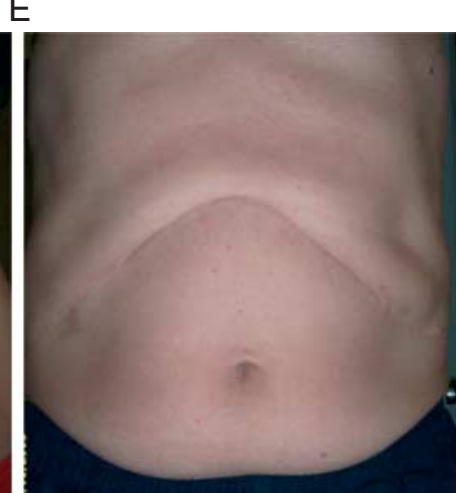

\section{Figure 1}

Pheochromocytomas and paragangliomas (arrows in A-E). (A) Bilateral adrenal tumors in multiple endocrine neoplasia type 2. Image: courtesy Martin K Walz, Huyssens Hospital, Essen, MD. (B) Extra-adrenal retroperitoneal pheochromocytoma, $\mathrm{CT}$. This giant tumor was endoscopically resected in $8.5 \mathrm{~h}$ by Martin Walz, Essen, by a bilateral retroperitoneal access with minimal scars. After dissection, the tumor was in situ cut into pieces and removed. Image: courtesy Schu-Ren Yang, MD, University Medical Center,
Freiburg. (C) Paravesical pheochromocytoma (paraganglioma) with postural catecholamine attacks, resected endoscopically by Martin Walz. Image: courtesy Schu-Ren Yang, MD, University Medical Center, Freiburg. (D) Thoracic left-sided pheochromocytoma (paraganglioma), resected endoscopically after intubation of the right lung and collapse of the left lung. Image: courtesy Schu-Ren Yang, MD, University Medical Center, Freiburg. (E) Scars after conventional (right) and endoscopic (left) surgery for pheochromocytoma. http://erc.endocrinology-journals.org DOI: $10.1530 /$ ERC-13-0528
(C) 2014 Society for Endocrinology Printed in Great Britain 
with new color-coded graphs as the core of the chapter. This 17 th edition was published in 2008 , followed by invitations for the 18th edition (2011) (Neumann 2008, 2011). I realized that moderate verbal strategies are successful and strengthened the indication for endoscopic tumor removal and organ-sparing procedures as well as for molecular genetic diagnosis and its clinical relevance.

\section{For the patients: labor of love and a necessity}

The research from projects on diseases with lifelong and next-generation relevance, especially with multi-organ involvement, should be made available to all patients. Thus, we give back, in part, what we learned from the patients, providing them with gene-specific risk profiles and best management. Starting in the mid-1980s, I invited patients with such hereditary tumors and also those with their sporadic counterparts to information evenings. This was followed by information booklets. But all this was incomplete if there were no standard user-friendly means for patient-to-patient communication. In this regard, I was visited by Ms Joyce Graff from the USA, who lost her husband to VHL and whose affected son received recommendations for overly aggressive kidney tumor surgery. Her amazing personality was able to change the situation completely. She organized with me the first patient-provider conference in 1994 in Kansas City. She founded and established the American VHL Self Support Group. In this context, she created a periodical for information for the patients; she organized the conferences year by year in different states of the USA and later also in other countries, and she was always ready to be on call. Thus, in 1998 with Joyce's inspiration, a German VHL self-support group was founded by Gerhard Alsmeier.

In contrast to VHL, such activities have no parallel for pheochromocytoma in general, but the pressure rose. So, I decided to write an information booklet for patients with pheochromocytoma, paraganglioma, and associated diseases. It became a book of 150 pages with many figures, graphs, and tables and also included general information on how to understand the terminology of the mutations. The response of the German patients was encouraging, and I decided to make the information accessible worldwide free of charge and in other languages on the Internet. At present, there are over 13 translations and more are planned.

\section{School of Freiburg}

Thanks to our many patients and to our many colleagues in different fields of medicine, the University Medical
Center of Freiburg has developed into a center of excellence for the management of VHL, pheochromocytoma-associated diseases and similar diseases. Cornerstones have been and remain Vera van Velthoven in neurosurgery, Dieter Schmidt in ophthalmology, Irina Mader in neuroradiology, Arnd-Oliver Schaefer in radiology, Damian Wild and Philipp Meyer in nuclear medicine, and Wolfgang Schultze-Seemann and Christian Leiber in urology. Many students wrote their thesis in medicine on the molecular and clinical aspects of a broad selection of various diseases. International collaborations were set up with the universities and cancer centers in Warsaw, Padova, Salamanca, Rome, Shanghai, and Madrid and included visits by guests in the laboratory and outdoor clinic in Freiburg. Common projects resulted in best-ranked theses by Zoran Erlic in Padova, Italy and Ioana Milos in Timisoara, Romania. Thus, the preventive medicine center became a model, and similar structures have been established as satellites abroad. In-house collaborations led to seven professorial theses; among these are those based on long-term collaborations with Sven Glaesker, neurosurgery, and Carsten Boedeker,

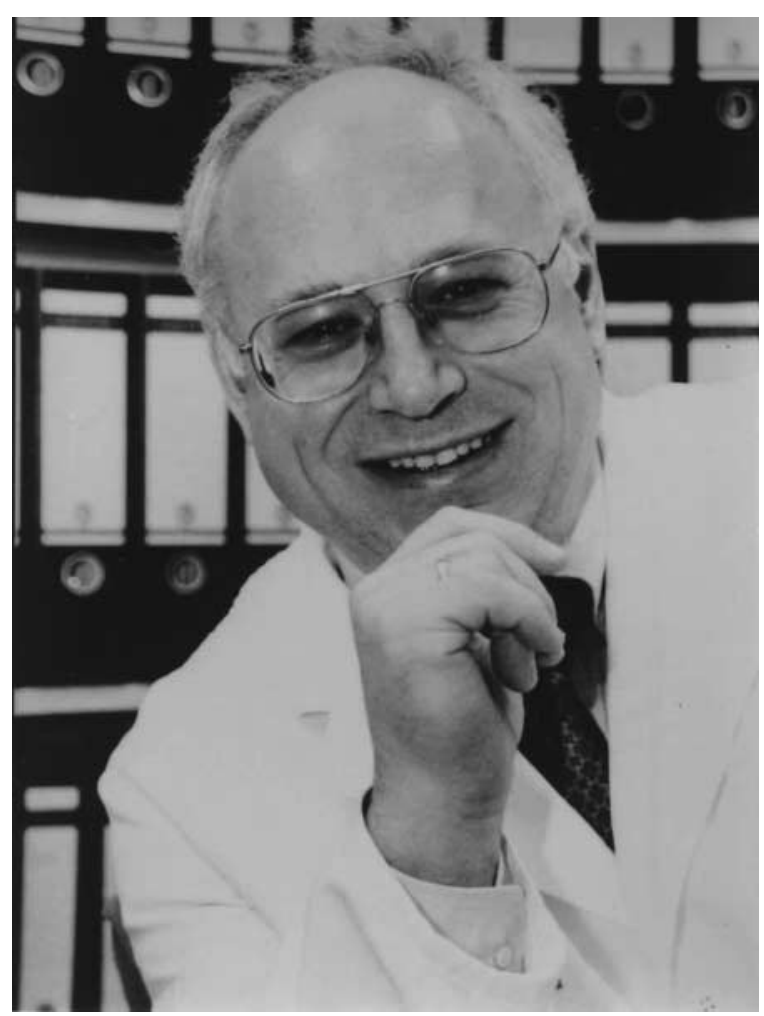

Figure 2

H P H Neumann when awarded with the Hufeland Prize in 1998.

Published by Bioscientifica Ltd. 


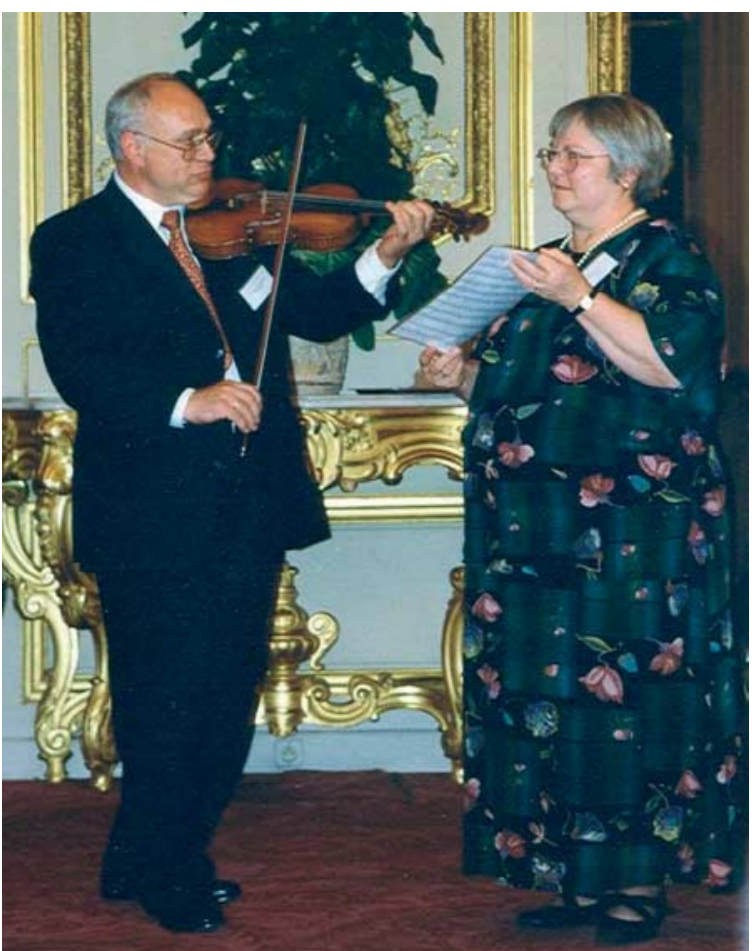

Figure 3

H P H Neumann with Joyce Graff at the 3rd International Symposium on VHL in Paris 1998.

otorhinolaryngology. In 1994, I organized a first scientific symposium on VHL in Freiburg, attended among others by Alfred Knudson Jr. This became a self-running international meeting of researchers and affiliated selfsupport groups every 2 years rotating through all parts of the world.

In 1998, I was honored by the Hufeland Prize, the German award for Preventive Medicine (Fig. 2). Later, VHL patients sent a letter to the President of Germany, Mr Horst Koehler, who awarded me with the Crossof-Merit of the Federal Republic of Germany in 2008. For long-lasting partnership with Tivadar Tulassay and Karoly Rács, the Semmelweis University of Budapest honored me with the degree of a doctor honoris causa in 2010.

\section{Outside medicine}

In 1985, I married Henriette Baroness von Krane-von Ficker. We have two daughters, Fanny and Luise. Words cannot express how grateful I am for the endless patience and support of my beloved wife. All collaborators and guests are invited to our home, meaning mainly her wonderful house where I always had and have the privilege of daily lunch. My passion is music (Fig. 3). Having been taught how to play violin from childhood, I spend much time in string quartets and amateur orchestras such as the Orchestra of the German Pediatricians. Since 2003, I have been a member of the Order of St John the Baptist.

\section{Admiration and partnership with the Grand Lady, Charis Eng}

Charis Eng (MD, PhD) is Director of the Genomic Medicine Institute at the Cleveland Clinic, before that a post-doctoral trainee in Cambridge, UK, subsequently working in faculty positions in Boston and Columbus, Ohio, with whom I have initiated many projects over the past 20 years. My admiration of her is sky-high. To date, we have 37 publications together, all in peer-reviewed journals (Mulligan et al. 1994, Eng et al. 1995a,b, Neumann et al. 1995, 2002, 2004, 2007, 2009, 2011, Marsh et al. 1997, Gimm et al. 2000, Bender et al. 2001, McWhinney et al. 2003, 2004, Vanharanta et al. 2004, Schiavi et al. 2005, Bausch et al. 2006a,b, 2007, 2013a,b, Cascon et al. 2008, Milos et al. 2008, Peczkowska et al. 2008a,b, Boedeker et al. 2009, Erlic et al. 2009, 2010a,b, Neumann \& Eng 2009, von Duecker et al. 2010, Bennett et al. 2011, Frank-Raue et al. 2011, Sullivan et al. 2011, Malinoc et al. 2012). I deeply regret that the distance between us has hindered personal meetings. But in early 2011, we had, after a very long while, a festive reunion in Cleveland (Fig. 4). In honor of her, I gave a violin recital

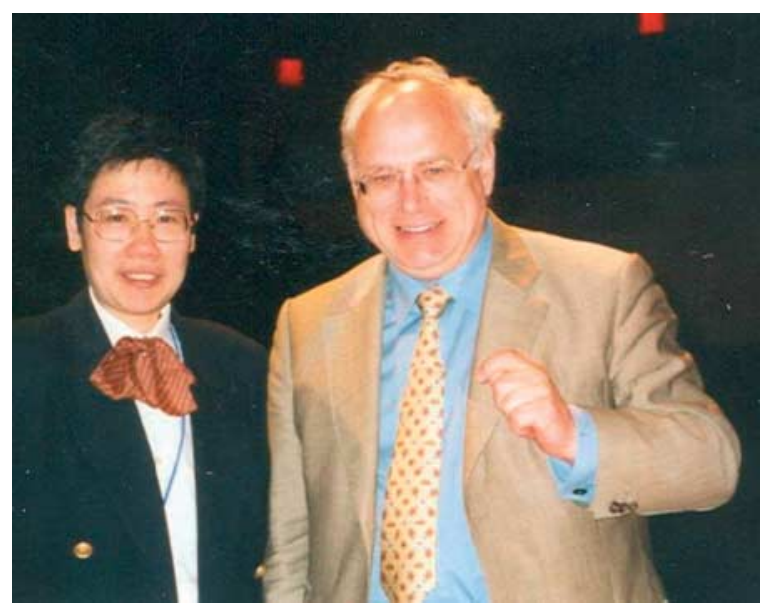

Figure 4

H P H Neumann and Charis Eng at the Symposium for MEN2 in Grand Rapids, Michigan, 2002.

Published by Bioscientifica Ltd. 
in the Miller Pavillon of the Cleveland Clinic accompanied by pianist Shuai Wang with Bach, Mozart, Beethoven, Massenet, and, as an encore, the Tango by Boulanger 'Avant de Mourir'.

I officially retired on 1st October 2013, and spent my last working day, September 30, in Nancy, where after many years of collaboration with my friend Georges Weryha, I was awarded a doctor honoris causa of the Université de Lorraine.

With 'retirement', I am looking forward to focusing more on science and my collaborations, always with my patients and the many colleagues who supported me over the past three decades in mind.

\section{References}

Bausch B, Boedeker CC, Berlis A, Brink I, Cybulla M, Walz MK, Januszewicz A, Opocher G, Eng C \& Neumann HPH 2006a Genetic and clinical investigation of pheochromocytoma: a 22-year experience, from Freiburg, Germany to International Effort. Annals of the New York Academy of Sciences 1073 112-121. (doi:10.1196/annals.1353.013)

Bausch B, Koschker AC, Fassnacht M, Stoevesandt J, Hoffmann MM, Eng C, Allolio B \& Neumann HPH 2006b Comprehensive mutation scanning of NF1 in apparently sporadic cases of pheochromocytoma. Journal of Clinical Endocrinology and Metabolism 91 3478-3481. (doi:10.1210/jc. 2006-0780)

Bausch B, Borozdin W, Mautner VF, Hoffmann MM, Boehm D, Robledo M, Cascon A, Harenberg T, Schiavi F, Pawlu C et al. 2007 Germline NF1 mutational spectra and loss-of-heterozygosity analyses in patients with pheochromocytoma and neurofibromatosis type 1. Journal of Clinical Endocrinology and Metabolism 92 2784-2792. (doi:10.1210/jc.20062833)

Bausch B, Jilg C, Gläsker S, Vortmeyer A, Lützen N, Anton A, Eng C \& Neumann HP 2013a Renal cancer in von Hippel-Lindau disease and related syndromes. Nature Reviews. Nephrology 9 529-538. (doi:10.1038/ nrneph.2013.144)

Bausch B, Wellner U, Bausch D, Schiavi F, Barontini M, Sanso G, Walz MK, Peczkowska M, Weryha G, Dall'igna P et al. 2013b Long term prognosis of patients with pediatric pheochromocytoma. Endocrine-Related Cancer 21 17-25. (doi:10.1530/ERC-13-0415)

Bender BU, Eng C, Olschewski M, Berger DP, Laubenberger J, Altehöfer C, Kirste G, Orzagh M, van Velthoven V, Miosczka H et al. 2001 No increased mortality from germline $V H L$ c.505 T > C mutation: the necessity of $V H L$ mutation-specific assessment. Journal of Medical Genetics 38 508-514. (doi:10.1136/jmg.38.8.508)

Bennett KL, Campbell R, Ganapathi S, Zhou M, Rini B, Ganapathi R, Neumann HP \& Eng C 2011 Germline and somatic DNA methylation and epigenetic regulation of KILLIN in renal cell carcinoma. Genes, Chromosomes \& Cancer 50 654-661. (doi:10.1002/gcc.20887)

Boedeker CC, Erlic Z, Richard S, Kontny U, Gimenez-Roqueplo AP, Cascon A, Robledo M, de Campos JM, van Nederveen FH, de Krijger RR et al. 2009 Head and neck paragangliomas in von Hippel-Lindau disease and multiple endocrine neoplasia type 2. Journal of Clinical Endocrinology and Metabolism 94 1938-1944. (doi:10.1210/jc.2009-0354)

Cascon A, Landa Í, López-Jiménez E, Díez-Hernández A, Buchta M, Montero-Conde C, Leskelä S, Leandro-Garciá LJ, Letón R, RodríguezAntona C et al. 2008 Molecular characterisation of a common SDHB deletion in paraganglioma patients. Journal of Medical Genetics $\mathbf{4 5}$ 233-238. (doi:10.1136/jmg.2007.054965)

Dluhy RG 2002 Death of an axiom. New England Journal of Medicine 346 1486-1488. (doi:10.1056/NEJM200205093461911) von Duecker L, Walz MK, Voss C, Arnold G, Eng C \& Neumann HP 2010 Laparoscopic organ-sparing resection of von Hippel-Lindau diseaseassociated pancreatic neuroendocrine tumors. World Journal of Surgery 35 563-567. (doi:10.1007/s00268-010-0878-5)

Eng C, Mulligan LM, Smith DP, Healey CS, Frilling A, Raue F, Neumann HPH, Pfragner R, Behmel A, Lorenzo MJ et al. 1995a Mutation of the RET proto-oncogene in sporadic medullary thyroid carcinoma. Genes, Chromosomes \& Cancer 12 209-212. (doi:10.1002/ gcc.2870120308)

Eng C, Mulligan LM, Smith DP, Healey CS, Frilling A, Raue F, Neumann HPH, Ponder MA \& Ponder BAJ 1995b Low frequency of germline mutations in the RET proto-oncogene in patients with apparently sporadic medullary thyroid carcinoma. Clinical Endocrinology 43 123-127. (doi:10.1111/j.1365-2265.1995.tb01903.x)

Erlic Z, Rybicki L, Peczkowska M, Golcher H, Kann PH, Brauckhoff M, Müssig K, Muresan M, Schäffler A, Reisch N et al. 2009 Clinical predictors and algorithm for the genetic diagnosis of pheochromocytoma patients. Clinical Cancer Research 15 6378-6385. (doi:10.1158/ 1078-0432.CCR-09-1237)

Erlic Z, Hoffmann MM, Sullivan M, Franke G, Peczkowska M, Harsch I, Schott M, Gabbert HE, Valimäki M, Preuss SF et al. 2010a Pathogenicity of DNA variants and double mutations in multiple endocrine neoplasia type 2 and von Hippel-Lindau syndrome. Journal of Clinical Endocrinology and Metabolism 95 308-313. (doi:10.1210/jc.2009-1728)

Erlic Z, Ploeckinger U, Cascón A, Hoffmann MM, von Duecker L, Winter A, Kammel G, Bacher J, Sullivan M, Isermann B et al. $2010 b$ Systematic comparison of sporadic and syndromic pancreatic islet cell tumors. Endocrine-Related Cancer 17 875-883. (doi:10.1677/ERC-10-0037)

Fränkel F 1886 Ein Fall von doppelseitigem, vollig latent verlaufenen Nebennierentumor und gleichzeitiger Nephritis mit Veranderungen am Circulationsapparat und Retinitis. Virchows Archiv für pathologische Anatomie und Physiologie und für klinische Medizin 103 244-263. (doi:10.1007/BF01938677)

Fränkel F 1984 Classics in oncology: a case of bilateral completely latent adrenal tumor and concurrent nephritis with changes in the circulatory system and retinitis: Felix Frankel, 1886. CA: A Cancer Journal for Clinicians 34 93-106. (doi:10.3322/canjclin.34.2.93)

Frank-Raue K, Rybicki LA, Erlic Z, Schweizer H, Winter A, Milos I, Toledo SP, Toledo RA, Tavares MR, Alevizaki M et al. 2011 Risk profiles and penetrance estimations in multiple endocrine neoplasia type 2A caused by germline RET mutations located in exon 10. Human Mutation 32 51-58. (doi:10.1002/humu.21385)

Gimm O, Armanios M, Dziema H, Neumann HPH \& Eng C 2000 Somatic and occult germline mutations ins $S D H D$, a mitochondrial complex II gene, in non-familial pheochromocytoma. Cancer Research 60 6822-6825.

Malinoc A, Sullivan M, Wiech T, Schmid KW, Jilg C, Straeter J, Deger S, Hoffmann MM, Bosse A, Rasp G et al. 2012 Biallelic inactivation of the SDHC gene in renal carcinoma associated with paraganglioma syndrome type 3. Endocrine-Related Cancer 19 283-290. (doi:10.1530/ ERC-11-0324)

Marsh DJ, Zheng Z, Arnold A, Andrew SC, Learoyd D, Frilling A, Komminoth P, Neumann HPH, Ponder BAJ, Rollins BJ et al. 1997 Mutation analysis of glial cell line-derived neurotropic factor (GDNF), a ligand for the RET/co-receptor complex, in MEN 2 and sporadic neuroendocrine tumors. Journal of Clinical Endocrinology and Metabolism 82 3025-3028.

McWhinney SR, Boru G, Binkley PK, Januszewicz A, Neumann HPH \& Eng C 2003 Intronic single nucleotide polymorphisms in the ret proto-oncogene are associated with a subset of apparently sporadic pheochromocytoma and may modulate age of onset. Journal of Clinical Endocrinology and Metabolism 88 4911-4916. (doi:10.1210/jc.2003030245)

McWhinney SR, Buchta M, Vanharanta S, Pezkowska M, Morrison CD, Virta SK, Lehtonen R, Järvinen H, Juhola M, Mecklin JP et al. 2004 Early onset renal cell carcinoma as novel extra-paraganglial component of 
SDHB-associated hereditable paraganglioma. American Journal Human Genetics 74 153-159. (doi:10.1086/381054)

Milos IN, Frank-Raue K, Wohllk N, Maia AL, Pusiol E, Patocs A, Robledo M, Biarnes J, Barontini M, Links TP et al. 2008 Age-related neoplastic risk profiles and penetrance estimations in multiple endocrine neoplasia type 2 A caused by germ line RET Cys634Trp (TGC>TGG) mutation. Endocrine-Related Cancer 15 1035-1041. (doi:10.1677/ERC-08-0105)

Mulligan LM 1993 Germline mutations of the RET protooncogene in multiple endocrine neoplasia type 2A. Nature 363 458-460. (doi:10.1038/363458a0)

Mulligan LM, Eng C, Healey CS, Clayton D, Kwok JBJ, Gardner E, Ponder MA, Frilling A, Jackson CE, Lehnert H et al. 1994 Specific mutations of the RET proto-oncogene are related to disease phenotype in MEN 2A and FMTC. Nature Genetics 6 70-74. (doi:10.1038/ng0194-70)

Neumann HPH 1987a Prognosis of Von Hippel-Lindau syndrome. VASA. Zeitschrift für Gefässkrankheiten 16 309-311.

Neumann HPH $1987 b$ Basic criteria for clinical diagnosis and genetic counsel-ling in Von Hippel-Lindau syndrome. VASA. Zeitschrift für Gefässkrankheiten 16 220-226.

Neumann HPH 2008 Pheochromocytoma. In Harrison's Principles of Internal Medicine, ch 337, 17th edn. Eds L Dan L Longo, Anthony S Fauci, Dennis L Kasper, Stephen L Hauser, J Larry Jameson \& Joseph Loscalzo. New York: McGraw Hill.

Neumann HPH 2011 Pheochromocytoma. In Harrison's Principles of Internal Medicine, ch 343, 18th edn. Eds Dan L Longo, Anthony S Fauci, Dennis L Kasper, Stephen L Hauser, J Larry Jameson \& Joseph Loscalzo. New York: McGraw Hill.

Neumann HPH \& Eng C 2009 The approach to the patient with paraganglioma. Journal of Clinical Endocrinology and Metabolism 94 2677-2683. (doi:10.1210/jc.2009-0496)

Neumann HPH \& Wiestler OD 1991 Clustering of features of Von Hippel-Lindau syndrome: evidence for a complex genetic locus. Lancet 337 1052-1054. (doi:10.1016/0140-6736(91)91705-Y)

Neumann HPH, Eggert H, Weigel K, Friedburg H, Wiestler O \& Schollmeyer P 1989 Hemangioblastomas of the central nervous system: a ten year study with special reference to Von Hippel-Lindau syndrome. Journal of Neurosurgery 70 24-30. (doi:10.3171/jns.1989. 70.1.0024)

Neumann HPH, Berger DP, Sigmund G, Blum U \& Parmer RJ 1993 Pheochromocytomas, multiple endocrine neoplasia type 2 , and von Hippel-Lindau syndrome. New England Journal of Medicine 329 1351-1358. (doi:10.1056/NEJM199311183292103)

Neumann HPH, Eng C, Mulligan LM, Glavac D, Zäuner I, Ponder BAJ, Crossey PA, Maher PR \& Brauch H 1995 Consequences of direct genetic testing for germline mutations in the clinical management of families with multiple endocrine neoplasia type 2. Journal of the American Medical Association 274 1149-1151. (doi:10.1001/jama.1995. 03530140061033)

Neumann HPH, Bender BU, Reincke M, Eggstein S, Laubenberger J \& Kirste G 1999 Adrenal sparing surgery for phaeochromocytoma. British Journal of Surgery 84 94-97. (doi:10.1046/j.1365-2168.1999.00974.x)

Neumann HPH, Bausch B, McWhinney SR, Bender BU, Gimm O, Franke G, Schipper J, Klisch J, Altehoefer C, Zerres K et al. 2002 Germ-line mutations in nonsyndromic pheochromocytoma. New England Journal of Medicine 346 1459-1466. (doi:10.1056/NEJMoa020152)

Neumann HPH, Pawlu C, Peczkowska M, Bausch B, McWhinney SR, Muresan M, Buchta M, Franke G, Klisch J, Bley TA et al. 2004 Distinct clinical features of paraganglioma syndromes associated with SDHB and SDHD gene mutations. Journal of the American Medical Association 292 943-951 (Erratum in: JAMA 2004 Oct 13; 292: 686). (doi:10.1001/ jama.292.8.943)

Neumann HPH, Vortmeyer A, Schmidt D, Werner M, Erlic Z, Cascon A, Bausch B, Januszewicz A \& Eng C 2007 Evidence of MEN-2 in the original description of classic pheochromocytoma. New England Journal of Medicine 357 1311-1315. (doi:10.1056/NEJMoa071407)

Neumann HPH, Erlic Z, Boedeker CC, Rybicki LA, Robledo M, Hermsen M, Schiavi F, Falcioni M, Kwok P, Bauters C et al. 2009 Clinical predictors for germline mutations in head and neck paraganglioma patients: cost reduction strategy in genetic diagnostic process as fall-out. Cancer Research 69 3650-3656. (doi:10.1158/0008-5472.CAN-08-4057)

Neumann HP, Sullivan M, Winter A, Malinoc A, Hoffmann MM, Boedeker CC, Bertz H, Walz MK, Moeller LC, Schmid KW et al. 2011 Germline mutations of the TMEM127 gene in patients with paraganglioma of head and neck and extraadrenal abdominal sites. Journal of Clinical Endocrinology and Metabolism 96 E1279-E1282. (doi:10.1210/jc.2011-0114)

Peczkowska M, Cascon A, Prejbisz A, Kubaszek A, Cwikła BJ, Furmanek M, Erlic Z, Eng C, Januszewicz A \& Neumann HPH 2008a Extra-adrenal and adrenal pheochromocytomas associated with a germline SDHC mutation. Nature Clinical Practice. Endocrinology \& Metabolism 4 111-115. (doi:10.1038/ncpendmet0726)

Peczkowska M, Erlic Z, Hoffmann MM, Furmanek M, Cwikla J, Kubaszek A, Prejbisz A, Szutkowski Z, Kawecki A, Chojnowski K et al. $2008 \mathrm{~b}$ Impact of screening kindreds for SDHD p.Cys11X as a common mutation associated with paraganglioma syndrome type 1. Journal of Clinical Endocrinology and Metabolism 93 4818-4825. (doi:10.1210/ jc.2008-1290)

Plate KH, Vortmeyer AO, Zagzag D \& Neumann HPH 2007 Chapter Von Hippel-Lindau disease and haemangioblastoma. In WHO Classification of Tumours of the Central Nervous System. Eds DN Louis, H Ohgaki, OD Wiestler \& WK Cavenee. Lyon: IARC Press.

Schiavi F, Boedeker CC, Bausch B, Peczkowska M, Gomez CF, Strassburg T, Pawlu C, Buchta M, Salzmann M, Hoffmann MM et al. 2005 Predictors and prevalence of paraganglioma syndrome associated with mutations of the SDHC gene. Journal of the American Medical Association 294 2057-2063. (doi:10.1001/jama.294.16.2057)

Sullivan M, Rybicki LA, Winter A, Hoffmann MM, Reiermann S, Linke H, Arbeiter K, Patzer L, Budde K, Hoppe B et al. 2011 Age-related penetrance of hereditary atypical hemolytic uremic syndrome. Annals of Human Genetics 75 639-647. (doi:10.1111/j.1469-1809.2011. 00671.x)

Vanharanta S, Buchta M, McWhinney SR, Virta SK, Peczkowska M, Morrison CD, Lehtonen R, Januszewicz A, Jarvinen H, Juhola M et al. 2004 Early-onset renal cell carcinoma as a novel extraparaganglial component of SDHB-associated heritable. American Journal of Human Genetics 74 153-159. (doi:10.1086/381054)

Received in final form 5 December 2013

Accepted 19 December 2013

Made available online as an Accepted Preprint

3 January 2014 http://erc.endocrinology-journals.org

DOI: 10.1530/ERC-13-0528
(C) 2014 Society for Endocrinology Printed in Great Britain
Published by Bioscientifica Ltd. 